\title{
Penyebaran Kutikula Pada Kerabang Telur Pada Usaha Peternakan Ayam Dengan Sistem Free Range
}

\section{The cuticle covers on eggshell within one production cycle of laying hens in free-range system}

\section{Elfira Kariane Suawa ${ }^{1)^{*}}$ and J R Roberts ${ }^{2)}$}

${ }^{1)}$ Fakultas Peternakan, Universitas Papua, Jl. Gunung Salju, Amban, Manokwari, Papua Barat

${ }^{2}$ Animal Science, school of Environmental and Rural Science, Woolshed Building (W49), University of New England, Armidale, New South Wales, 2351 Australia

\section{Article history \\ Received: Jun 8, 2021; \\ Accepted: Dec 23, 2021 \\ * Corresponding author: \\ E-mail: \\ e.suawa@unipa.ac.id \\ DOI: \\ 10.46549/jipvet.v11i3.227

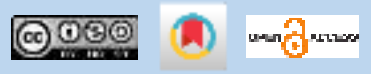

\begin{abstract}
The cuticle is the outermost layer of the egg which deposited on to the surface of the egg during the final 1-1.5 hours prior to oviposition. It is a protective coating which prevents bacterial penetration through the gas exchange pores in the eggshell. The aim of this research is analysing the cuticle cover and ultrastructural features of the mammillary layer cover during production cycle in the free-range system. Data were collected from age 26,37, 50 and 60 weeks of age to observe the eggshell colour (\%), cuticle cover following the MST blue dye which analysed by spectrophotometry based on $\mathrm{L}^{*} \mathrm{a} * \mathrm{~b}$ system and scanning electron microscopy (SEM). Data were analysed using Statview Software (SAS Institute Inc., Version 5.0.1.0). A two way analysis of variance was conducted taking flock age and shed/flock as the independent variables and body weight, egg quality measurements, spectrophotometry ( $\left.\mathrm{L}^{*} \mathrm{a} * \mathrm{~b}\right)$ measurements, single score measurements for cuticle cover, and ultrastructural features as dependent variables. Level of significance was indicated by probability of less than 5\%. The Fishers PLSD test was used to differentiate between mean values. The result of this research showed that the cuticle cover is vary from age to age. The greater value of cuticle cover in at 37 weeks of age which the same result also showed by single scrore and SEM. The cuticle cover of the shell is mostly affected by age and also strain.
\end{abstract}

Keyword: Cuticle; Eggshell quality; Laying hens.

\section{Abstrak}

Kutikula pada telur merupakan lapisan terluar telur yang dideposisikan pada lapisan palisade kurang lebih 1,5-2 jam di akhir pembentukan kerabang di dalam uterus. Kutikula berfungsi sebagai benteng pertahanan pertama untuk mencegah masuknya bakteri ke dalam telur. Penelitian ini dilakukan pada usaha peternakan ayam petelur yang dipelihara dengan system free range. Telur diambil untuk dianalisa penyebaran kutikula telur pada umur 26, 37, 50, dan 60 minggu. Variable yang diamati meliputi reflektifitas warna kerabang (\%), penyebaran kutikula diukur menggunakan MST blue dye dan selanjutnya diukur melalui sistim spectrophotometry, yang difokuskan pada sistim pewarnaan berdasarkan sistim $\mathrm{L} * \mathrm{a} * \mathrm{~b} *$ dan single score, dan dilanjutkan dengan pengamatan menggunakan scanning electron microscopy (SEM).Selanjutnya data dianalisis menggunakan Staview software (SAS Institute Inc. version 5.0.1.0) dengan analisis anova dua arah, dimana umur ayam sebagai variable independent dan nilai SCI a* sesudah perendaman dan nilai single score $\left(\Delta \mathrm{E}^{*} \mathrm{ab}\right)$ sebagai variable dependent, pada level of significance 5\%. Pengaruh yang nyata diuji lanjut menggunakan Fisher PLSD. Pada penelitian ini didapatkan bahwa penyebaran kutikula pada kerabang telur bervariasi selama pengamatan. Penyebaran kutikula terbanyak ditemukan pada 
saat ayam berumur 37 minggu. Hal ini juga diperkuat dengan hasil yang diperoleh dengan single score $\left(\Delta \mathrm{E}^{*}{ }_{\mathrm{ab}}\right)$ yang memperlihatkan nilai $\Delta \mathrm{E}^{*}{ }_{\mathrm{ab}}$ yang tinggi pada umur 37 minggu. Penyebaran kutikula pada kerabang telur sangat dipengaruhi oleh umur dan juga strain ayam.

Kata kunci: Ayam petelur; Kualitas telur; Kutikula.

\section{PEN D AH ULUAN}

Kutikula merupakan lapisan terluar dari telur yang tidak terlihat namun merupakan lapisan terluar dari telur yang mengandung bahan organic dan zat pewarna kerabang, yang berfungsi sebagai pelindung untuk mencegah masuknya bakteri kedalam telur melalui poripori. Kutikula merupakan lapisan organic yang mengandung $90 \%$ protein dan $10 \%$ lemak yang dideposisikan pada permukaan telur pada 1-1.5 jam sebelum oviposisi (Baker \& Balch, 1962; Nys et.al., 2004). Selanjutnya Dennis et al. (1996) melaporkan bahwa kutikula juga mengandung glikoprotein, polisakarida, lemak dan anorganik fosfor termasuk kristal hysoxyapatite. Sedikitnya terdapat 47 jenis protein yang telah diidentifikasi terdapat pada lapisan terluar kutikula, serta dua protein yang hampir sama dengan Kunitz-like protease inhibitor dan ovocalyxin-32 (a carboxypeptidase a inhibitor) dilaporkan merupakan komposisi terbesar dalam protein kutikula (Rose-Martel et.al., 2012). Ketebalan kutikula disekitar permukaan kerabang sangat bervariasi antara $0.5-12.8 \mu \mathrm{m}$, dan terbaik terdapat pada area dekat pori. Keberadaan kutikula pada kerabang juga akan mempengaruhi ketebalan kerabang yang secara langsung juga berkaitan dengan kekuatan kerabang. Selanjutnya Sparks and Board (1984) melaporkan bahwa ketebalan kutikula pada kerabang akan semakin berkurang seiring dengan bertambahnya umur ayam. Akan tetapi pernyataan ini tidak seiring dengan penelitian Roberts et.al., (2013) yang tidak mendapatkan perbedaan yang nyata dari pengaruh umur flock pada system kandang terhadap ketebalan kutikula pada kerabang. Selanjutnya Ruiz and Lunam (2000) melaporkan bahwa lapisan kutikula yang tebal ditemukan pada saat puncak produksi dibandingkan pada awal atau akhir periode bertelur pada broiler breeder. Demikian pentingnya fungsi kutikula sebagai benteng pertahanan telur sehingga penelitian ini dilakukan untuk mendalami lebih lanjut pengaruh umur ayam terhadap keberadaan ataupun penyebaran kutikula pada kerabang.

\section{MATERI DAN METODE}

Telur pengamatan diambil dari usaha peternakan ayam yang dipelihara dengan system free-range. Pengamatan kutikula telur dilakukan pada saat ayam berumur 26, 3750 dan 60 minggu, sebanyak 30 butir. Pengukuran kutikula kerabang dilakukan sebelum dan sesudah telur direndam dalam larutan MST kutikula blue dye selama 1 menit (Gambar 1), dan dibilas pada air mengalir. Reflektifitas warna kerabang diukur menggunakan reflectometer (Technical Services and Supply, TSS, UK), dengan range warna 0-100 (hitam ke putih). Warna kerabang diukur menggunakan Konica Minolta spectrophotometer (CM2600d). Pengamatan spectrophotometry terhadap penyebaran kutikula telur dilakukan pada saat sebelum dan sesudah mencelupkan telur dalam larutan MST blue dye berdasarkan pengamatan sistim nilai warna $\mathrm{L}^{*} \mathrm{a} * \mathrm{~b}$. Nilai $\mathrm{L}^{*}$ memiliki nilai range maksimum100 (putih) dan minimum nilai 0 (hitam). Warna hijau diindikasikan oleh nilai $-\mathrm{a}^{*}$ dan merah oleh nilai $+\mathrm{a}^{*}$. Warna biru diindikasikan oleh nilai $b^{*}$ dan kuning oleh nilai $+b^{*}$. Kemudian dihitung nilai single score $\left(\Delta \mathrm{E}^{*} \mathrm{ab}\right)$ kutikula berdasarkan Leleu et al., (2011). Pengamatan kemudian dilanjutkan dengan menggunakan SEM untuk melihat struktur kutikula pada telur. Data selanjutnya dianalisa menggunakan Staview software (SAS Institute Inc. Version 5.0.1.0) menggunakan analisis Anova dua arah dimana umur ayam sebagai variable independent dan nilai SCI $\mathrm{a}^{*}$ sesudah perendaman dan nilai single score $\left(\Delta \mathrm{E}^{*} \mathrm{ab}\right)$ sebagai variable dependent, dengan level of significance $5 \%$, kemudian perbedaan yang significant diuji lanjut menggunakan Fisher PLSD. 

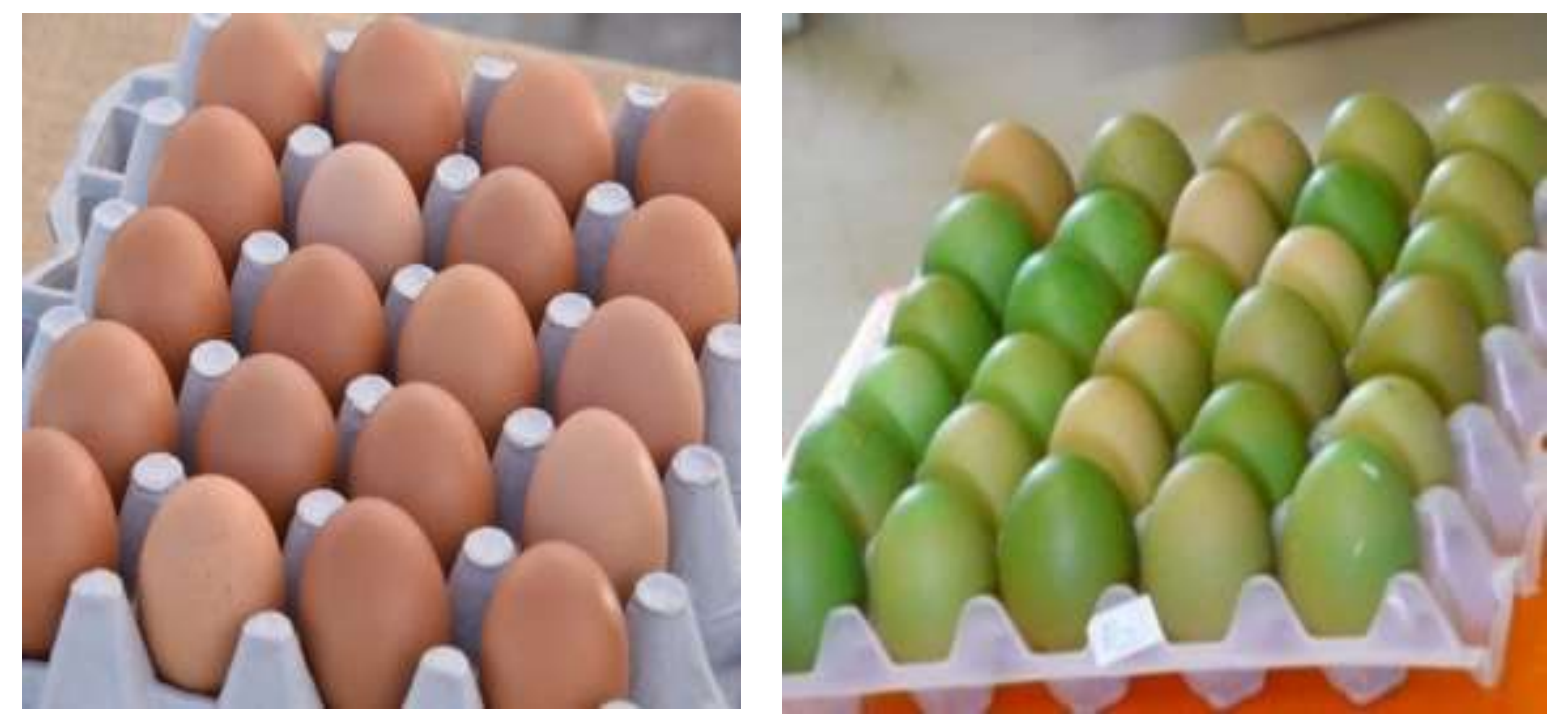

Gambar 1. Telur sebelum direndam dalam MST blue dye (kiri); telur setelah direndam dalam MST blue dye (kanan)

\section{HASI L DAN PEMBAH ASAN}

Tabel 1 menyajikan data jumlah kutikula yang terdapat pada kerabang telur menggunakan reflectometer (\%) dan spectrophotometry berdasarkan sistim pewarnaan $\mathrm{L} * \mathrm{a} * \mathrm{~b}$, serta nilai single score $\left(\Delta \mathrm{E}_{\mathrm{ab}}\right)$ sebelum dan setelah perendaman dalam blue dye pada beberapa kategori umur.

Tabel 1. Pengamatan pada reflektifitas dan spektrofotomertri penyebaran kutikula pada kerabang

\begin{tabular}{|c|c|c|c|c|c|}
\hline \multirow{2}{*}{$\begin{array}{l}\text { Variable } \\
\text { pengamatan }\end{array}$} & \multicolumn{4}{|c|}{ Umur ayam (minggu) } & \multirow{2}{*}{ P Value } \\
\hline & 26 & 37 & 50 & 60 & \\
\hline \multicolumn{6}{|c|}{ Refleksi warna kerabang (\%) sebelum perendaman } \\
\hline $\mathrm{L}^{*}$ & $29.0 \pm 0.28^{c}$ & $31.0 \pm 0.31^{\mathrm{a}}$ & $29.9 \pm 0.29^{b}$ & $30.9 \pm 0.36^{\mathrm{a}}$ & $<0.0001$ \\
\hline$a^{*}$ & $59.5 \pm 0.37^{\mathrm{c}}$ & $63.0 \pm 0.29^{\mathrm{a}}$ & $62.1 \pm 0.23^{b}$ & $63.4 \pm 0.29^{\mathrm{a}}$ & $<0.0001$ \\
\hline \multirow[t]{2}{*}{$b^{*}$} & $18.1 \pm 0.13^{\mathrm{a}}$ & $17.6 \pm 0.14^{\mathrm{b}}$ & $17.2 \pm 0.14^{\mathrm{c}}$ & $16.1 \pm 0.16^{\mathrm{d}}$ & $<0.0001$ \\
\hline & $29.1 \pm 0.21^{\mathrm{a}}$ & $29.2 \pm 0.16^{\mathrm{a}}$ & $28.8 \pm 0.16^{\mathrm{a}}$ & $28.2 \pm 0.16^{\mathrm{b}}$ & $<0.0001$ \\
\hline \multicolumn{6}{|c|}{ Refleksi warna kerabang (\%) Sesudah perendaman } \\
\hline $\mathrm{L}^{*}$ & $54.2 \pm 0.37^{\mathrm{c}}$ & $56.3 \pm 0.31^{\mathrm{b}}$ & $56.2 \pm 0.29^{b}$ & $58.0 \pm 0.35^{\mathrm{a}}$ & $<0.0001$ \\
\hline$a^{*}$ & $1.5 \pm 0.34^{\mathrm{a}}$ & $-0.7 \pm 0.36^{b}$ & $-0.1 \pm 0.42^{b}$ & $0.1 \pm 0.39^{b}$ & $<0.0001$ \\
\hline$b^{*}$ & $32.9 \pm 0.18^{a}$ & $31.6 \pm 0.16^{b}$ & $31.3 \pm 0.16^{b c}$ & $31.1 \pm 0.19^{c}$ & $<0.0001$ \\
\hline$\Delta \mathrm{Eab}$ & $18.5 \pm 0.43^{b}$ & $19.9 \pm 0.39^{\mathrm{a}}$ & $18.8 \pm 0.45^{b}$ & $17.4 \pm 0.44^{\mathrm{c}}$ & $<0.0001$ \\
\hline
\end{tabular}

a, b, c Huruf yang berbeda diantara kolom menunjukkan perbedaan yang sangat nyata.

Terdapat perbedaan yang sangat nyata dari umur ayam terhadap refleksi warna kerabang sebelum dan sesudah perendaman serta pada sistim nilai warna $\mathrm{L}^{*} \mathrm{a} \mathrm{b}^{*}$. Refleksi warna kerabang berfluktuasi dengan umur ayam, dimana nilai refleksi warna kerabang terendah berada pada umur 26 minggu dan nilai refleksi warna kerabang tertinggi berada pada umur 37 minggu. Pola yang sama juga ditemukan dengan menggunakan sistim nilai pewarnaan sistim L*a*b*. Gambar 1 menunjukkan adanya korelasi yang sangat significant $\left(\mathrm{R}^{2}=0.8183\right)$ antara refleksi warna kerabang $(\%)$ dan nilai $\mathrm{L}^{*}$ sebelum perendaman dalam blue dye. Nilai $\mathrm{L}^{*}$ sesudah perendaman dengan blue dye meningkat seiring dengan bertambahnya umur ayam dengan nilai tertinggi pada umur 60 minggu dan terendah pada umur 26 minggu. 
Pada penelitian ini terlihat bahwa umur ayam memiliki pengaruh yang sangat nyata terhadap refleksi warna kerabang telur. Refleksi warna kerabang telur semakin meningkat seiring dengan peningkatan umur ayam menunjukan bahwa warna kerabang telur semakin memudar seiring dengan bertambahnya umur ayam. Hasil ini juga sejalan dengan penelitian yang dilakukan oleh (Roberts \& Chousalkar, 2014) yang mendapatkan bahwa warna kerabang telur akan lebih gelap pada saat ayam berumur antara 2537 minggu sedangkan warna kerabang yang lebih cerah atau putih ditemukan pada umur ayam yang semakin semakin tua. Nilai $b^{*}$ relative constant pada sebelum perendaman kemudian menurun pada umur 60 minggu. Nilai $b^{*}$ sesudah perendaman menurun seiring dengan peningkatan umur ayam. Telur yang tidak memiliki cukup kutikula atau yang sudah tercuci menjadi sangat rentan terhadap contaminasi bakteri (De Reu et al., 2008; Bain, 2005). Lebih lanjut disampaikan oleh De Reu et al., (2008) bahwa cuticula yang menyelimuti telur memainkan peranan yang sangat penting

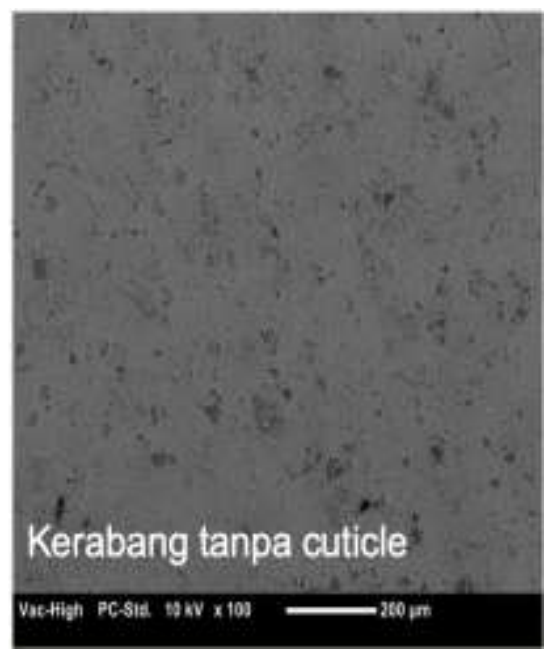

untuk menghambat masuknya bacteri ke dalam telur. Selanjutnya juga dijelaskan bahwa komposisi kimia kerabang menjadi sangat penting dalam menghambat penetrasi bakteri ke dalam telur. Wellman-Labadie et al., (2008) menjelaskan bahwa protein yang diekstrak dari kutikula telur dari beberbagai jenis unggas memiliki aktifitas penghambat beberapa jenis bakteri. Dennis et al., (1996) melaporkan bahwa kutikula tersusun atas glikoprotein, polisakarida, lemak dan inorganic fosfor termasuk kristal hidroxyapatit. Kemudian Du (2013) menyatakan bahwa 90\% komponen organic terbesar yang terkandung dalam kutikula adalah protein berupa sistine, glicin, asam glutamate, lisin dan tirosin. Selanjutnya komponen lemak yang dieksktrak dari kutikula juga memiliki potensi sebagai antimicrobial (Wellman-Labadie et al., 2008). Lebih lanjut Rose-Martel et al., (2012), menemukan sejumlah jenis protein yang terdapat dalam kutikula (e.g., lysozyme C, ovotransferrin, ovocalyxin-32, and ovocleidin-17) diketahui memiliki aktifitas antimikrobial.

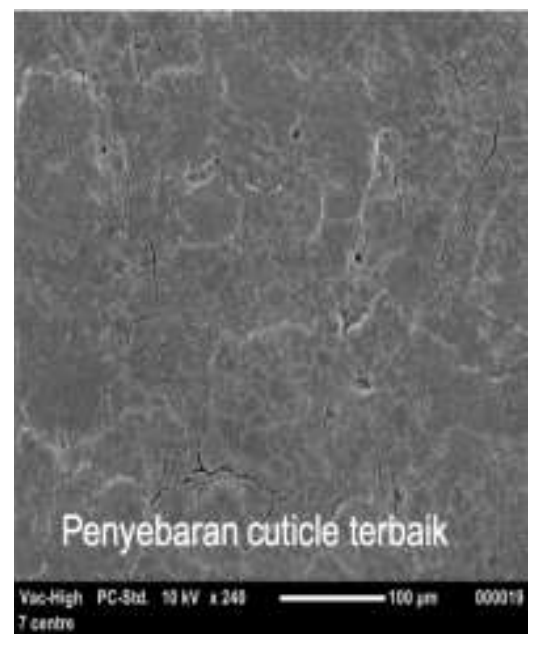

\section{Gambar 2. Gambaran kutikula di lihat di bawah SEM}

Hasil yang diperoleh untuk nilai a* setelah perendaman menunjukkan bahwa jumlah kutikula yang banyak terbentuk pada saat ayam berumur 37 minggu, sedangkan jumlah kutikula sangat sedikit ditemukan pada saat ayam berumur 26 minggu. Hal ini mengindikasikan bahwa penyebaran jumlah kutikula pada kerabang sangat sedikit pada saat ayam berumur 26 minggu, umur dimana ayam baru mulai bertelur, sedangkan penyebaran jumlah kutikula terbanyak ditemukan pada saat ayam berumur 37 minggu (-0.7 \pm 0.36$)$, umur dimana ayam mulai memasuki pucak produksi, walaupun nilai ini tidak berbeda nyata dengan penyebaran jumlah kutikula pada saat ayam berumur 50 dan 60 minggu. Hal ini juga dibuktikan dengan nilai single score $\left(\Delta \mathrm{E}_{\mathrm{ab}}\right)$ dan pengamatan SEM (Scanning Electron Microscopy) yang tinggi pada umur ayam 37 minggu. Menurut Sparks and Board (1984) 
jumlah penyebaran kutikula akan menurun secara significant seiring dengan bertambahnya umur ayam, akan tetapi Roberts et al. (2013) tidak menemukan perbedaan yang significant antara umur ayam dan jumlah penyebaran kutikula pada telur. Kusuda et al (2011) dan Dennis et al. (1996) melaporkan bahwa ketebalan kutikula pada kerabang bervariasi antara $0,5-12,8 \mu \mathrm{m}$ dengan penyebaran terbaik berada dekat pori dimana kutikula akan mengisi dan membentang sekeliling pori. Hal ini sejalan dengan fungsi kutikula dimana bersama-sama dengan proses mineralisasi kerabang dan selaput telur, kutikula berperan mengkontrol penguapan air dalam telur, serta sebagai pertahanan utama untuk mencegah masukknya bakteri atau mikroorganisme ke dalam telur (De Reu et al., 2008; Hincke et al., 2008). Rodriguez-Navaro et al., (2013) mengkonfirmasi bahwa komponen kimia yang terdapat dalam cuticle merupakan bagian yang sangat penting dalam menghambat penetrasi bakteri dan kolonisasi bakteri pada permukaan telur. Selanjutnya, Suawa, Roberts, and Parkinson (2016) melaporkan bahwa berat badan pada saat umur pertama bertelur serta keseragaman berat badan awal flock sangat berpengaruh terhadap penyebaran kutikula pada kerabang, akan tetapi hal ini juga berbeda antara flock yang satu ke flock yang lain pada sistim pemeliharaan yang sama. Umur dan strain ayam sangat berpengaruh terhadap penyebaran kutikula pada kerabang telur.

\section{KESI MPULAN}

Kutikula memegang peranan yang sangat penting dalam menjaga kualitas isi telur. Ketersediaan kutikula yang cukup pada kerabang dapat menghambat masuknya mikroorganisme ke dalam telur yang dapat menurunkan dan merusak kualitas telur. Penyebaran jumlah kutikula sangat tinggi pada saat ayam berada pada puncak produksi 37 minggu dan semakin menurun dengan bertambahnya umur. Akan tetapi masih perlu dilakukan penelitian lebih lanjut tentang fatorfaktor lain seperti jenis pakan yang dapat mempengaruhi ketersediaan kutikula pada kerabang.

\section{DAFTAR PUSTAKA}

Bain, M. M. (2005) Recent advances in the assessment of eggshell quality and their future application. World's Poultry Science Journal, 61(02), 268-277.

Baker J, \& Balch D. (1962) A study of the organic material of hen's-egg shell. Biochemical Journal, 82: 352-361.

De Reu K, Messens W, Heyndrickx M, Rodenburg T, Uyttendaele M, Herman L. (2008) Bacterial contamination of table eggs and the influence of housing systems. World's Poultry Science Journal, 64(01): 5-19.

Dennis JE, Xiao SQ, Agarwal M, Fink DJ, Heuer AH, Caplan AI. (1996) Microstructure of matrix and mineral components of eggshells from white leghorn chickens (Gallus gallus). Journal of Morphology, 228(3): 287-306.

Du, J. (2013). Chicken Eggshell Membrane and Cuticle: Insight from Bioinformatics and Proteomics. (Master of Science), University of Ottawa, Ottawa, Canada.

Hincke MT, Wellman-Labadie O, McKee MD, Gautron J, Nys Y, Mann K. (2008) Biosynthesis and structural assembly of eggshell components. Egg Bioscience and Biotechnology, 97-128.

Kusuda, S., Iwasawa, A., Doi, O., Ohya, Y., \& Yoshizaki, N. (2011) Diversity of the cuticle layer of avian eggshells. The journal of poultry science, 11022201001102220100.

Leleu S, Messens W, Reu KD, Preter SD, Herman L, Heyndrickx M, Baerdemaeker JD, Michiels CW, Bain M. (2011) Effect of egg washing on the kutikula quality of brown and white table eggs. Journal of Food Protection $\AA$, 74(10): 1649-1654.

Nys Y, Gautron J, Garcia-Ruiz JM, Hincke MT. (2004) Avian eggshell mineralization: biochemical and functional characterization of matrix proteins. Comptes Rendus Palevol, 3(6): 549-562.

Roberts J, Chousalkar K, Samiullah S. (2013) Egg quality and age of laying hens: implications for product safety. Animal Production Science, 53(12): 1291-1297.

Roberts J, Chousalkar K. (2014) Effect of production system and flock age on egg 
quality and total bacterial load in commercial laying hens. The Journal of Applied Poultry Research, 23(1): 59-70.

Rodríguez-Navarro, A. B., Domínguez-Gasca, N., Muñoz, A., \& Ortega-Huertas, M. (2013) Change in the chicken eggshell cuticle with hen age and egg freshness. Poultry Science, 92(11), 3026-3035.

Rose-Martel M, Du J, Hincke MT. (2012) Proteomic analysis provides new insight into the chicken eggshell kutikula. Journal of ,Proteomics, 75(9): 2697-2706.

Ruiz J, and Lunam C. (2000) Ultrastructural analysis of the eggshell: Contribution of the individual calcified layers and the kutikula to hatchability and egg viability in broiler breeders. British Poultry Science, 41(5): 584-592.

Sparks N, Board R. (1984) Cuticle, shell porosity and water uptake through hens' eggshells. British Poultry Science, 25(2): 267-276.

Suawa EK, Roberts J, Parkinson G. (2016) Body weight uniformity and eggshell quality of hens in a free-range production system. In: the 27Th. Australian Poultry Science Symposium, Sydney, Australia, 1417 February 2016.

Wellman-Labadie, O., Picman, J., \& Hincke, M. T. (2008) Antimicrobial activity of cuticle and outer eggshell protein extracts from three species of domestic birds. British poultry science, 49(2), 133-143. 